\title{
The Involvement of Glutamate Metabolism in the Resistance to Thermal, Nutritional, and Oxidative Stress in Trypanosoma cruzi
}

\author{
Anahí Magdaleno, Brian Suárez Mantilla, Sandra C. Rocha, Elizabeth M. F. Pral, \\ and Ariel M. Silber
}

Departamento de Parasitología, Instituto de Ciências Biomédicas, Universidade de São Paulo, Av. Prof. Lineu Prestes 1374, CEP 05508-900, São Paulo, Brazil

Correspondence should be addressed to Ariel M. Silber, asilber@usp.br

Received 16 December 2010; Accepted 17 February 2011

Academic Editor: Claudio Alejandro Pereira

Copyright () 2011 Anahí Magdaleno et al. This is an open access article distributed under the Creative Commons Attribution License, which permits unrestricted use, distribution, and reproduction in any medium, provided the original work is properly cited.

The inhibition of some glutamate metabolic pathways could lead to diminished parasite survival. In this study, the effects of Lmethionine sulfoximine (MS), DL-methionine sulfone (MSO), and DL-methionine sulfoxide (MSE), three glutamate analogs, on several biological processes were evaluated. We found that these analogs inhibited the growth of epimastigotes cells and showed a synergistic effect with stress conditions such as temperature, nutritional starvation, and oxidative stress. The specific activity for the reductive amination of $\alpha$-ketoglutaric acid, catalyzed by the $\mathrm{NADP}^{+}$-linked glutamate dehydrogenase, showed an increase in the $\mathrm{NADP}^{+}$levels, when MS, MSE, and MSO were added. It suggests an eventual conversion of the compounds tested by the T. cruzi cells. The fact that trypomastigote bursting was not significantly inhibited when infected cells were treated with these compounds, remarks the existence of relevant metabolic differences among the different life-cycle stages. It must be considered when proposing a new therapeutic drug.

\section{Introduction}

Chagas' disease, also known as American trypanosomiasis, is a parasitic illness caused by the hemoflagellate Trypanosoma cruzi, which is transmitted to humans by blood-sucking triatomine vectors. The parasite is prevalent in South and Central America and infects $12-15$ million people in the region, with approximately 40,000 new cases per year, and approximately 12,500 deaths per year due to cardiac disease (WHO, http://www.who.int/tdr/). In addition, more than 100,000 chronically infected individuals currently reside in the United States, Canada, and Europe due to migration from endemic countries [1]. At present, no clinically approved drug exists for the satisfactory treatment of chronic stage of the infection. Benznidazole and nifurtimox are the only available drugs prescribed for T. cruzi and are $60-80 \%$ effective in the treatment of acute infection, but the use of these drugs to treat the chronic phase remains controversial due to their low effectiveness and high toxicity. As a consequence of the adverse reactions, oral treatments frequently have to be discontinued [2]. The limitations of existing therapies encourage the search for alternative new drugs for both the acute and chronic treatment of Chagas' disease.

T. cruzi has a complex life cycle, alternating between the insect vector and the mammalian vertebrate host, which may include humans. The parasite presents different stages during the cycle: epimastigotes (replicative and noninfective forms in the insect vector), bloodstream and metacyclic trypomastigotes (nonreplicative and infective forms to vertebrate host cells), and amastigotes (intracellular and replicative forms of the vertebrate host) [3-5]. These different forms of the parasite must adapt to the changes of the particular environment inside the insect vector and vertebrate host cells, such as temperature, $\mathrm{pH}$, and nutrient availability.

Amino acids are crucial nutrients during the T. cruzi life cycle, because they can be used as carbon and energy sources [6] and can participate in several biological processes that help the parasite adjust to these environmental changes. 
<smiles>NC(CCC(=O)O)C(=O)O</smiles>

L-glutamic acid

(a)<smiles>CS(=O)CCC(N)C(=O)O</smiles>

L-methionine sulfoxide (MSE)

(c)

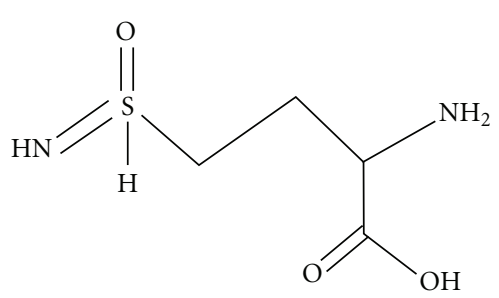

L-methionine sulfoximine (MS)

(b)

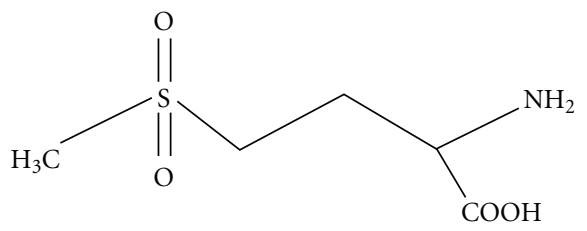

L-methionine sulfone (MSO)

(d)

FIGURE 1: Chemical structures of the compounds used in this study.

For example, arginine metabolism is coupled to $T$. cruzi growth [7] and is involved in the management of cell energy under conditions of $\mathrm{pH}$ and nutritional stress [8]. Proline, glutamate, and aspartate are essentials in the differentiation process from epimastigote to metacyclic trypomastigote (metacyclogenesis) $[9,10]$. More specifically, proline, an amino acid metabolically related to glutamate, seems to have a broad variety of functions: it fulfills the energy requirements for host cell invasion [11] and growth in lowglucose environments such as the host-cell cytoplasm [12], it is involved in the differentiation from the intracellular transient epimastigote-like stage to trypomastigote forms [13], and recently, it has been shown to be involved in mechanisms of resistance to oxidative stress [14]. The amino acid glutamate is directly involved in osmoregulation and cell volume control $[15,16]$. Taking into account the important biological functions of amino acids in T. cruzi, it has been hypothesized that some components of their metabolic pathways could serve as possible therapeutic targets against Chagas' disease [6].

The uptake of glutamate occurs in epimastigotes and trypomastigotes cells through a single kinetic transport system, which is driven by the cytoplasmic membrane $\mathrm{H}^{+}$concentration gradient [17]. Inside the cell, it could be converted into $\alpha$-ketoglutarate by the glutamate dehydrogenase and processed via the Krebs cycle to obtain energy [18-20]. Both isoforms of this enzyme also participate in the biosynthesis of glutamate by their ability to incorporate $\mathrm{NH}_{3}$ into $\alpha$ ketoglutarate [21]. According to nutritional requirements, $T$. cruzi can incorporate L-glutamate into proteins, or transfer the carbon chain to the metabolism of arginine or proline via $\Delta^{1}$-pyrroline-5-carboxylate dehydrogenase [6]. Interestingly, L-glutamate can also serve as a substrate for glutathione synthesis via $\gamma$-glutamylcysteine synthetase and glutathione synthetase [22]. Glutathione can, in turn, act as a substrate for the synthesis of trypanothione, a milestone metabolite in the regulation of the redox state of the intracellular medium in trypanosomas [23]. Furthermore, glutamine can be synthesized from glutamate and ammonia in the presence of glutamine synthetase [21]. As this reaction is reversible, it is possible for glutamine to be oxidized through the glutamate pathway. All these glutamate pathways could be targets of inhibition by structural or functional analogs of this amino acid, the common substrate of most of the key enzymes related to glutamate metabolism.

The effects of several glutamate analogs have been analyzed in prokaryotic and eukaryotic organisms, showing inhibitory effects on some enzymatic functions. L-methionine sulfoximine (MS), L-methionine sulfone (MSO), and DL-methionine sulfoxide (MSE) (Figure 1) were found to be potent inhibitors of both enzymes, glutamate synthetase [24] and glutamine synthetase [25-27] in bacteria. In the present work, we analyze the effects of three glutamate analogs MS, MSE, and MSO on the growth and survival of T. cruzi epimastigotes and on trypomastigote bursting from infected host cells. We also investigated the synergism or antagonism of these analogs with the thermal, oxidative, and nutritional stress, conditions that T. cruzi is subjected to along its natural life cycle. The effect of these compounds on the specific activity for three glutamate-related enzymatic reactions was also evaluated.

\section{Results and Discussion}

The possible trypanocidal or trypanostatic effects of the three glutamate analogs, MS, MSE, and MSO, were investigated in T. cruzi epimastigotes. The growth of epimastigotes on LIT medium with or without $200 \mu \mathrm{M}$ rotenone and $0.5 \mu \mathrm{M}$ antymicin [28] was used as a control. The epimastigotes 


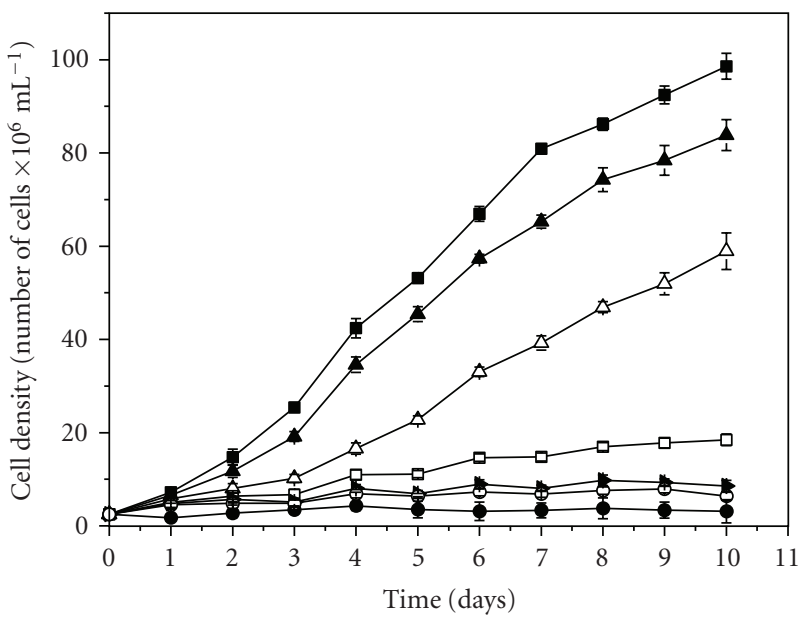

(a)

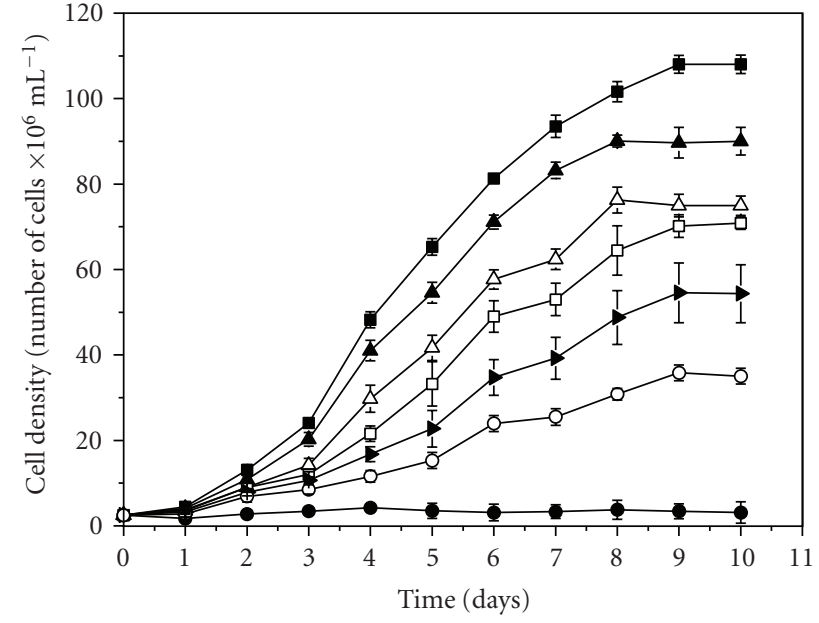

(b)

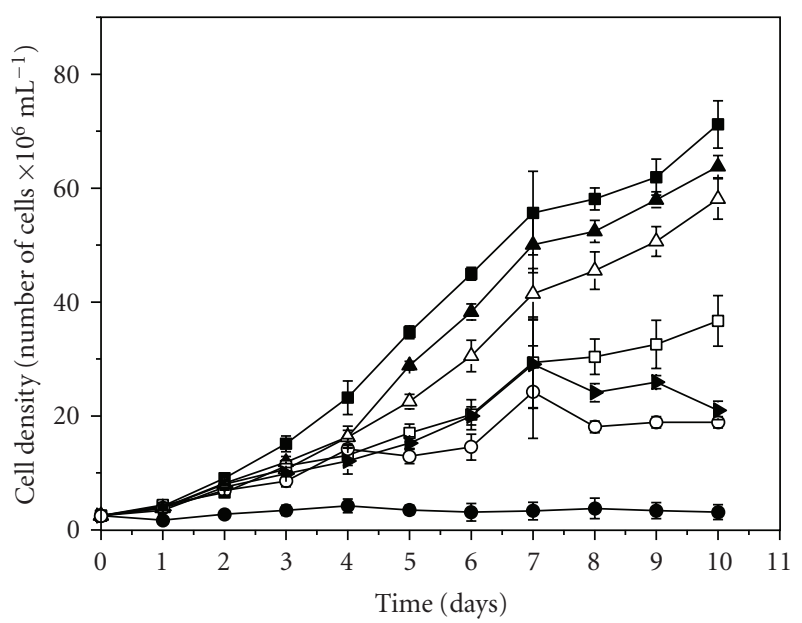

(c)

FIgURE 2: Growth curve of epimastigotes of Trypanosoma cruzi treated with MS (a), MSE (b) or $\mathrm{MSO}$ (c) at $28^{\circ} \mathrm{C}$ and $\mathrm{pH} 7.5$ : $0 \mathrm{mM}, \Delta \mathrm{MS}=10 \mathrm{mM}, \mathrm{MSE}=20 \mathrm{mM}, \mathrm{MSO}=15 \mathrm{mM} ; \triangle \mathrm{MS}=20 \mathrm{mM}, \mathrm{MSE}=40 \mathrm{mM}, \mathrm{MSO}=30 \mathrm{mM} ; \square \mathrm{MS}=30 \mathrm{mM}, \mathrm{MSE}=60 \mathrm{mM}$, $\mathrm{MSO}=45 \mathrm{mM} ; \mathrm{MS}=40 \mathrm{mM}, \mathrm{MSE}=80 \mathrm{mM}, \mathrm{MSO}=60 \mathrm{mM} ; \bigcirc \mathrm{MS}=50 \mathrm{mM}, \mathrm{MSE}=100 \mathrm{mM}, \mathrm{MSO}=75 \mathrm{mM}$. Positive control $(\bullet)$ was used with $0.5 \mu \mathrm{M}$ antimycin and $200 \mu \mathrm{M}$ rotenone.

reached the maximum cell density, at values between $71 \pm$ $4 \times 10^{6}$ cells $\mathrm{mL}^{-1}$ and $108 \pm 2 \times 10^{6}$ cells $\mathrm{mL}^{-1}$, at the ninth or tenth day of growth in LIT (Figure 2). All three glutamate analogs showed a dose-dependent inhibition on epimastigote growth with significant differences between the cells treated with drugs and controls $(P<.01)$. The $\mathrm{IC}_{50}$ values estimated at the fifth day of growth were higher for MSO and MSE $(52.6 \pm 4.3 \mathrm{mM}$ and $58.8 \pm 3.3 \mathrm{mM}$, resp.) than for MS (17.0 \pm $0.3 \mathrm{mM})$. MS and MSO are well characterized as inhibitors of prokaryotic and eukaryotic glutamine synthetase [25, 26, 29, 30], whereas MSE inhibits the enzyme glutamate synthetase [24]. Since the $\mathrm{IC}_{50}$ values are high (more than 50-times) when compared with the $\mathrm{Km}$ reported for the glutamate transporter $(0.3 \mathrm{mM})$ [17], it seems that these compounds are not acting as efficient glutamate uptake inhibitors. On the other hand, since measured enzyme activities are not abolished, the fact that these compounds could be acting with low efficiency on several targets cannot be ruled out. Further experiments of glutamate and glutamine-uptake, in the presence of MS, MSE and MSO as competitors, will be done in order to determine if these transport systems are inhibited.

Until now, no glutamate synthetase activity or putative genes coding for this enzyme had been identified in T. cruzi. However, the T.cruzi $\mathrm{NADP}^{+}$-linked glutamate dehydrogenase is a very well characterized enzyme, both at molecular and biochemical level [18, 20, 31]. Previous data have demonstrated the presence of the genes coding (accession numbers: Tc00.1047053505843.10 and Tc00.1047053508111.30 http://www.tritrypdb.org/) for the $\mathrm{NADP}^{+}$-linked glutamate dehydrogenase on T. cruzi [32]. The first of these alleles is the only one with published data on the expression level along the T. cruzi life cycle. It was found that the corresponding mRNA are 
downregulated in the trypomastigote stage and upregulated in the epimastigote stage. No significant variations were reported for amastigotes or metacyclic trypomastigote stages [33]. This enzyme catalyses reversibly the formation of glutamate on T. cruzi. Adittionally, we have identified two putative sequences for glutamine synthetase (accession numbers: Tc00.1047053508175.370 and Tc00.1047053503405.10, http://www.tritrypdb.org/). The transcriptome analysis shows that the glutamine synthase mRNA is down-regulated in the amastigote stage and upregulated in the metacyclic trypomastigote stage with respect to the epimastigote or trypomastigotes stages [33]. Both essentiability and druggability parameters were investigated in The TDR Targets Database v4 (http://www .tdrtargets.org/) for both gene products: glutamate dehydrogenase and glutamine synthase. The only sequence for which the data were available was that corresponding to the glutamate dehydrogenase allele (Tc.00.1047053507875.20). This sequence was defined as a non-essential gene. In addition, no druggability data were found.

The first assumption of the functionality of a GS was previously reported [21]. We confirmed the functionality of this biosynthetic step by measuring the GS specific activity in crude extracts from epimastigotes forms $(32 \pm 3 \mathrm{U} / \mathrm{mg}$ protein, Figure $7(\mathrm{c}))$. The cloning of this genes and its biochemical characterization are necessary to extrapolate these data with the measurements in the parasite. However, no significant differences on the specific activity for GS were observed in the presence of MS, MSE or MSO. The fact that the $\mathrm{IC}_{50}$ values for both MSE and MSO are similar gives support to the conversion of MSE into MSO [34], both acting directly or indirectly on the same metabolic target. It was also remarkable that the $\mathrm{IC}_{50}$ obtained for $T$. cruzi was higher than that obtained for other organisms [24, 25, 30]. In view of this, it seems likely that these two compounds are metabolized to molecules that are less toxic to the parasite, or that are converted to methionine as described for some bacteria, yeast, and mammalian organisms [35].

MS, which was proposed as a drug candidate against tuberculosis [26, 27] and was successfully evaluated in cancer therapy [36], showed the highest toxicity for T. cruzi epimastigotes $(17.0 \pm 0.3 \mathrm{mM})$. MS is a well-characterized inhibitor of glutamine synthetase in mammalians $[26,27$, $37,38]$ that could cause an abnormal increase of glutamate in astroglia, producing seizures and toxicity in animals [39]. However, no significant inhibitory effect was observed on the GS activity, from T. cruzi, when MS or other one analog (MSE, MSO) were tested. In spite of requiring high doses to inhibit T. cruzi growth, several factors affecting MS selectivity could be optimized based on several strategies. It should be taken into account that the evaluated MS in this study was the racemic form $(S / R)$, which is the only one commercially available. Usually, only one of the enantiomers has biological activity. From previous studies, It is likely that the S-enantiomer is active against glutamine synthetase [40]. A stereospecific preparation of this drug will probably result in a 2- to 5-fold reduction of the $\mathrm{IC}_{50}$, as described for Mycobacterium tuberculosis [26]. These data suggest that the inhibitory effect on T. cruzi demonstrated in this study could
TABLE 1: The effects of the temperature on $\mathrm{IC}_{50}$ values. The $\mathrm{IC}_{50}$ values were obtained by adjusting the data to a dose-response sigmoid equation for each glutamate analog at the three culture temperatures.

\begin{tabular}{lccc}
\hline Temperature & MS & MSE & MSO \\
\hline $28^{\circ} \mathrm{C}$ & $17.0 \pm 0.3$ & $58.8 \pm 3.3$ & $52.6 \pm 4.3$ \\
$33^{\circ} \mathrm{C}$ & $20.2 \pm 1.7$ & $47.1 \pm 7.9$ & $32.4 \pm 3.2$ \\
$37^{\circ} \mathrm{C}$ & $9.4 \pm 1.5$ & $37.2 \pm 2.6$ & $11.1 \pm 0.7$ \\
\hline
\end{tabular}

be largely optimized by using the appropriate enantiomer. Additionally, a quantitative determination of the glutamate content would help to determine if the parasite is converting the analogs in consumable substrates.

When T. cruzi invades the mammalian host cell, it is exposed to different environmental changes. Among these changes are the acidic medium of the parasitophorous vacuole, the reactive oxygen species (ROS) produced by the host cells, changes in the nutrients availability, and high temperature of mammalian host. All these factors acting simultaneously with drugs could reduce parasite viability, revealing the role of their targets on the resistance to these stress conditions. We evaluated the viability of epimastigotes under the interaction of analogs with thermal, nutritional and oxidative stress. For thermal stress, we chose three temperatures: $28^{\circ} \mathrm{C}$, the optimal temperature of growth for the insect vector stages, $37^{\circ} \mathrm{C}$, the temperature of the mammalian host, and $33^{\circ} \mathrm{C}$, the optimal temperature for the progression of in vitro infection of mammalian cells [13]. As previously reported [14], the maximum cell density (between $99 \pm 4 \times 10^{6}$ cells $\mathrm{mL}^{-1}$ and $141 \pm 4 \times 10^{6}$ cells $\mathrm{mL}^{-1}$ ) was reached when cultures were maintained at $33^{\circ} \mathrm{C}$ in spite of the fact that Asin and Catala observed an optimum temperature of $28^{\circ} \mathrm{C}$ [41], a discrepancy that can likely be attributed to differences in the T. cruzi strain (Figure 2). When the parasites were cultured at $37^{\circ} \mathrm{C}$ (nearly the human temperature), the maximum cell density $(28 \pm 2 \times$ $10^{6}$ cells $\times \mathrm{mL}^{-1}$ ) diminished with respect to the standard epimastigote temperature $\left(91 \pm 3 \times 10^{6}\right.$ cells $\left.\times \mathrm{mL}^{-1}\right)$ [14] . The $\mathrm{IC}_{50}$ was obtained for each analog and temperature. Results indicated that the sensitivity of parasites to the drugs was significantly increased with temperature (Table 1) being that the synergistic interaction between these factors was significant at $37^{\circ} \mathrm{C}(P<.01)$ (Figure 3$)$. Interestingly, the highest inhibitory interaction between a specific analog and temperature was observed with $\mathrm{MSO}$ at $37^{\circ} \mathrm{C}$, which produced an almost 5 -fold reduction in the $\mathrm{IC}_{50}$ compared to that obtained at $28^{\circ} \mathrm{C}$ (Table 1 ).

To analyze the possible effect of drugs on nutritionally stressed parasites, three different carbon sources were added separately to each culture (glucose, glutamate, and proline). The parasite can metabolize glutamate and proline to obtain energy as well as glucose [6]. Then, the epimastigotes were starved for $72 \mathrm{~h}$ in PBS (PBS) or in $3 \mathrm{mM}$ glucose (GLC), 3 mM L-glutamate (GLU), or $3 \mathrm{mM} \mathrm{L-proline} \mathrm{(PRO),}$ separately. The cultures were treated with the analogs at concentrations near the $\mathrm{IC}_{50}$ obtained for parasite growth. 


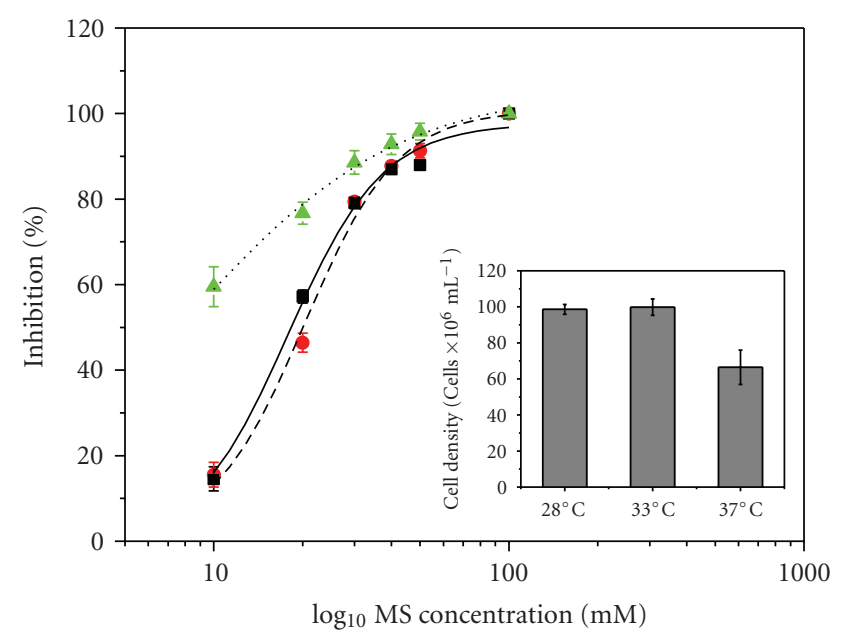

(a)

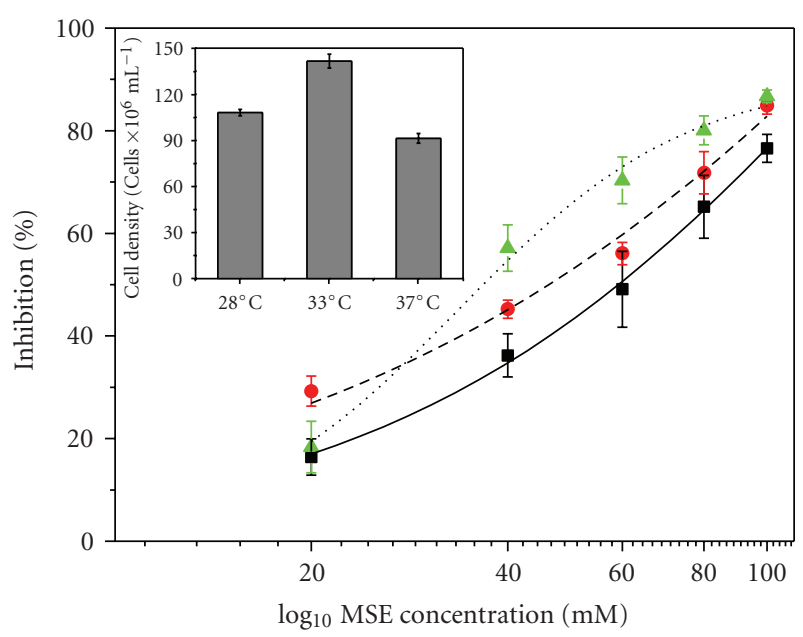

(b)

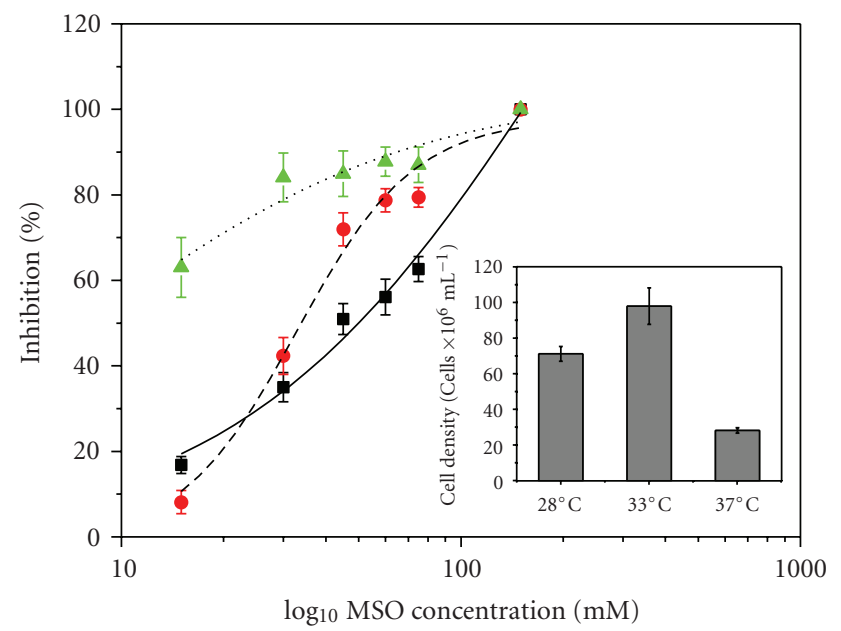

(c)

Figure 3: Dose-response curves of epimastigotes cultured at different temperatures and concentrations of MS (a), MSE (b), and MSO (c) treatment. The parasite growth inhibition was measured on the fifth day of growth, submitted to thermal stress $\left(\bullet 33^{\circ} \mathrm{C}\right.$, and $\left.\mathbf{\Delta} 37^{\circ} \mathrm{C}\right)$ or not $\left(\square 28^{\circ} \mathrm{C}\right)$ and drug treatments. The curves correspond to the adjusting to sigmoidal dose-response equation at $28^{\circ} \mathrm{C}(-), 33^{\circ} \mathrm{C}(---)$, and $37^{\circ} \mathrm{C}(\cdots)$. Insets: the maximum cell growth obtained in the control (no drug treatment) for each temperature is shown.

Untreated cells were used as controls. As expected, the presence of the three different carbon sources contributed to maintain parasite viability when compared with those starved in just PBS (Figure 4). Each culture treated with inhibitors showed significant differences $(P<.01)$ when compared to controls, except for those incubated with PBS and MSE. Furthermore, MS and MSO produced greater inhibition than MSE (Table 2). Again, these results indicate that MSE may not be an effective inhibitor against T. cruzi. As evidenced in Figure 4 and Table 2, MS reversed the effect of glutamate on viability, confirming that this analog interferes with glutamate metabolism.

To analyze the effect of each drug on parasites subjected to oxidative stress, the cultures were incubated for $90 \mathrm{~min}$ with PBS supplemented with or without $120 \mu \mathrm{M} \mathrm{H}_{2} \mathrm{O}_{2}$ and $10 \mathrm{mM}$ MS, $30 \mathrm{mM}$ MSE, and $25 \mathrm{mM}$ MSO. The combined treatment with $\mathrm{H}_{2} \mathrm{O}_{2}$ and MSO or MSE showed a statistically
TABLE 2: The effect of the nutritional state of the parasites on treatment with glutamate analogs. The inhibitory percentages (\%) were calculated from the viability of the epimastigotes obtained in each starved condition with or without the addition of drug $(\mathrm{MS}=20 \mathrm{mM}, \mathrm{MSE}=60 \mathrm{mM}$, and $\mathrm{MSO}=50 \mathrm{mM})$.

\begin{tabular}{lccc}
\hline Nutrients & MS & MSE & MSO \\
\hline PBS (no nutrients) & 87 & 18 & 51 \\
GLC & 55 & 38 & 84 \\
L-GLU & 90 & 44 & 77 \\
L-PRO & 56 & 43 & 68 \\
\hline
\end{tabular}

significant synergistic effect $(P<.01)$, whereas MS did not show synergism (Figure 5). Following a previously presented rationale [14], it could be proposed that the augmented effect of the analogs in the presence of $\mathrm{H}_{2} \mathrm{O}_{2}$ was due to the fact that these reagents affected glutamate- or glutamine-dependent 


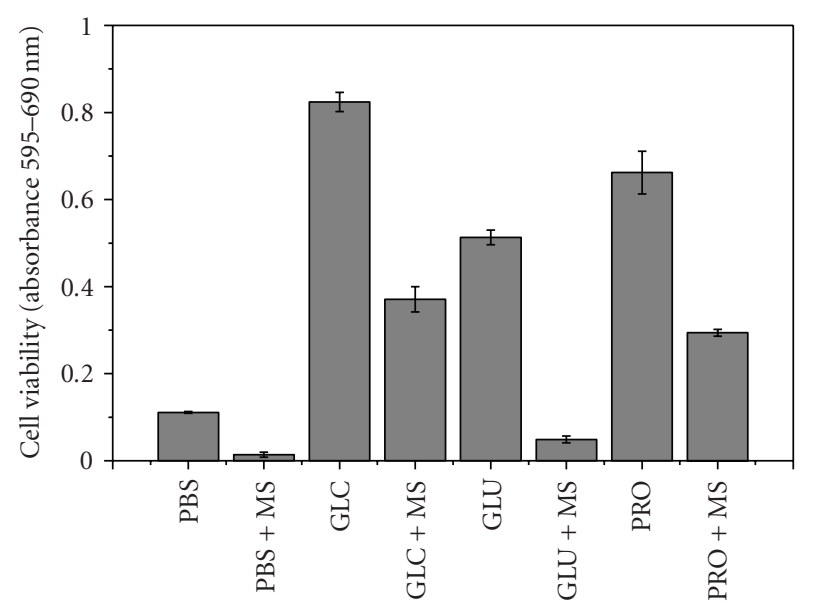

(a)

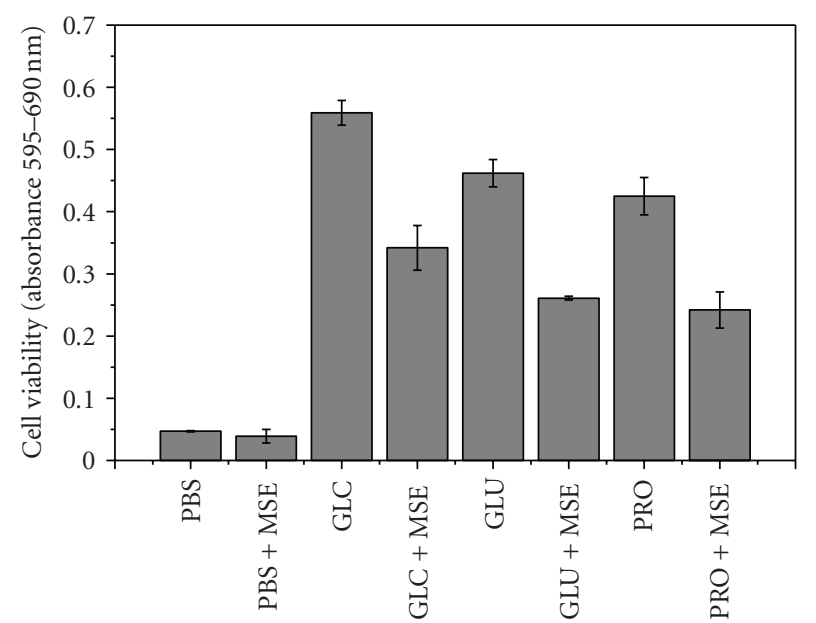

(b)

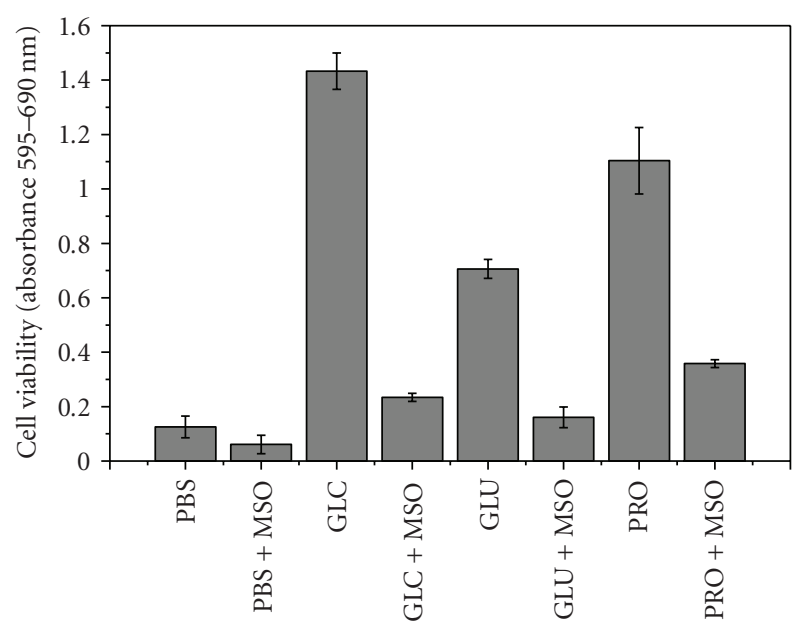

(c)

FIGURe 4: Response of epimastigotes to nutritional stress and MS (a), MSE (b), or MSO (c) treatment. Parasites were incubated for $72 \mathrm{~h}$ in PBS, $3 \mathrm{mM}$ glucose (GLC), $3 \mathrm{mM}$ glutamate (GLU), or $3 \mathrm{mM}$ proline (PRO), and treated with $20 \mathrm{mM} \mathrm{MS}, 60 \mathrm{mM}$ MSE, or $50 \mathrm{mM}$ MSO. The cell viability was evaluated using the MTT assay.

oxidative stress resistance mechanisms. Alternatively, it could be argued that the enhancement of the effects of the analogs seen under oxidative stress conditions was due to the fact that these compounds made the cells more fragile by partially arresting glutamate or glutamine metabolism.

To better understand both the involvement of glutamate/glutamine metabolism in resistance to oxidative and metabolic stresses as well as the interaction between these factors and MSE, MSO, or MS treatments, a three-variable experiment was performed: cell viability was evaluated as a function of oxidative and metabolic stress challenges and MSE, MSO, or MS treatment. The parasites were maintained for $48 \mathrm{~h}$ at the conditions previously described for the nutritional stress experiment, then washed with PBS and incubated for $3 \mathrm{~h}$ with or without $80 \mu \mathrm{M} \mathrm{H} \mathrm{H}_{2} \mathrm{O}_{2}$. After incubation, cell viability was evaluated. All three drugs significantly diminished $(P<.05)$ the epimastigote viability after the 3-h incubation (with or without oxidative stress) with respect to those not subjected to preincubation (named To, see Figure 6). The absence of treatment with analogs resulted in a diminished effect of oxidative stress $(P<.01)$. The protection observed in parasites maintained in $3 \mathrm{mM}$ L-proline against oxidative stress had been previously reported for several organisms $[42,43]$ and for T. cruzi [14]. In the same way, the glutamate analogs could act as possible coadjuvants for therapeutic drugs by enhancing the parasite sensitivity to ROS generated by the treatment with nifurtimox or benznidazole [22]. The interaction between the analogs and $\mathrm{H}_{2} \mathrm{O}_{2}$ was only synergistic $(P<.05)$ when the parasites were previously incubated with glucose and MS or MSE, glutamate and MSO, or proline and MSO (Figure 6). As expected, these results confirmed that the nutritional state of the parasites is a main factor to be taken into account in the interpretation of these assays. Most importantly, these data showed the existence of at least three oxidative-stress resistance mechanisms involving glutamaterelated metabolic pathways: (1) MS and MSE interfere with a glucose-dependant mechanism, (2) MSO, as expected, 


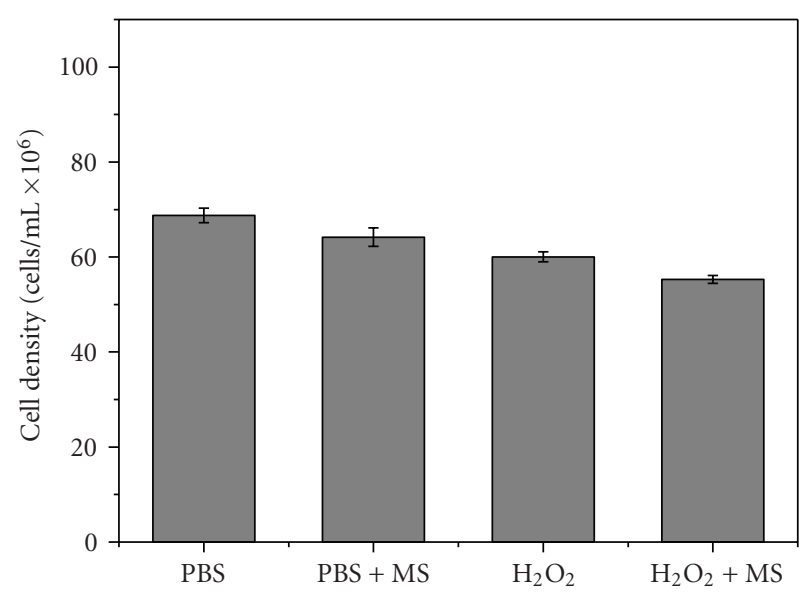

(a)

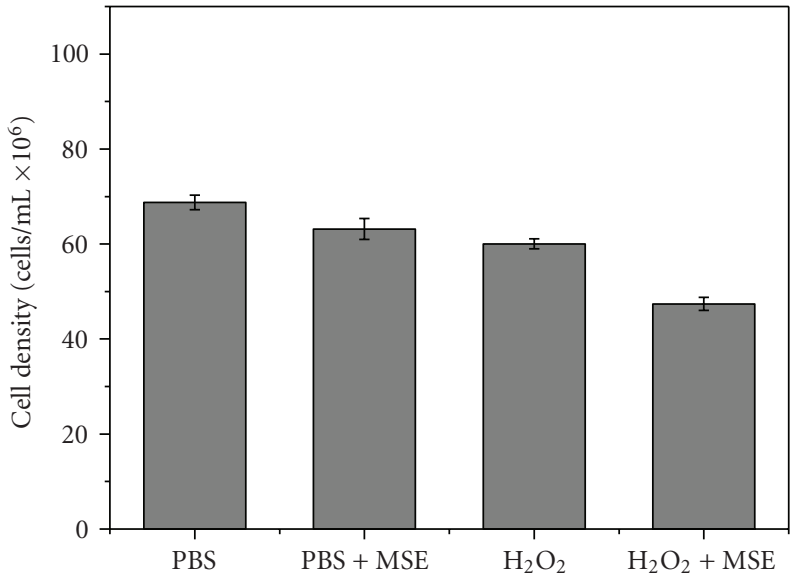

(b)

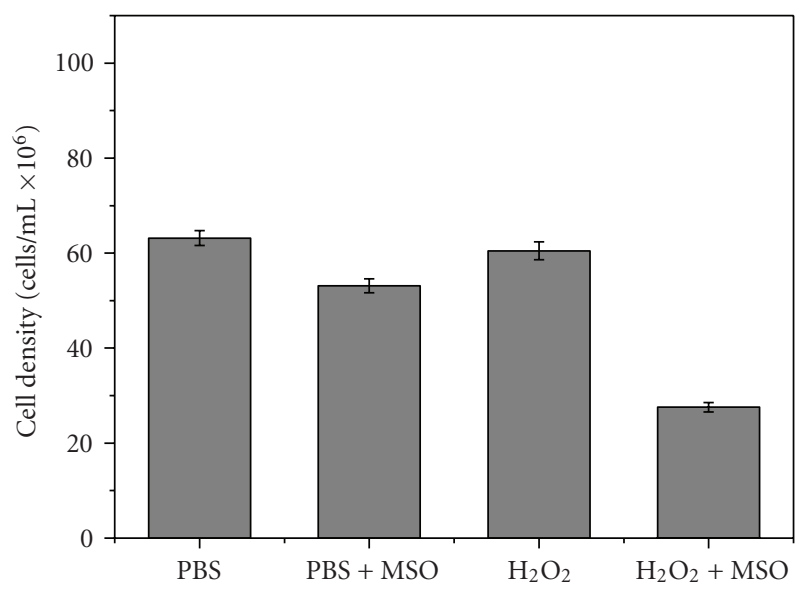

(c)

Figure 5: Response of epimastigotes to oxidative stress and MS (a), MSE (b), or MSO (c) treatment. Exponential growth culture parasites (control samples and samples treated with $10 \mathrm{mMMS}, 30 \mathrm{mM} \mathrm{MSE}$, or $25 \mathrm{mM}$ MSO) were resuspended in PBS and subjected either to oxidative stress for $3 \mathrm{~h}$ by addition of $120 \mu \mathrm{M} \mathrm{H}_{2} \mathrm{O}_{2}$ or to water as the control. After washings, cells were cultured in LIT and counted after 5 days to evaluate their recovery after treatments.

interferes with a glutamate-dependant mechanism, and (3) MSO also interferes with a proline-dependant mechanism. Other protection mechanisms that could be altered by the tested analogs cannot be discarded. For example, it is known that ROSs can oxidize the surface-exposed methionine residues of proteins to methionine sulfoxides and this damage could be repaired by two methionine sulfoxide reductases $[44,45]$, a mechanism that occurs throughout the aerobic world, from bacteria [35] to mammals [45, 46]. The interconversion of methionine and methionine sulfoxide can function as a natural process to regulate the biological activity of proteins [47]. Mechanisms that protect cells against oxidative-stress are mainly important in the in vivo infection establishment, or when parasites are exposed to drugs used in the treatment of Chagas' disease [22].

The effect of these three glutamate analogs on the hostcell viability (see Figure S1 in Supplementary Material available online at doi: 10.4061/2011/486928) and on the host cell infection by trypomastigotes (Figure S2, Supplementary
Material) were also evaluated at three concentrations of each drug (MS $=10-20 \mathrm{mM}, \mathrm{MSO}=30-50 \mathrm{mM}$, and MSE $=30-$ $50 \mathrm{mM}$ ). No significant inhibition on the trypomastigote burst was observed (data not shown). This fact, together with recent findings showing the inability of trypomastigotes to recover the ATP levels after starvation on the basis of glutamate as the sole carbon source [11], strongly supports the idea that, for these forms, glutamate-based metabolism is not relevant as glucose- or proline-based metabolism. However, it should be taken into account that the mode of action of nifurtimox and benznidazole includes free radicals (nitroradicals) and the generation of electrophilic metabolites, both of which are toxic for all forms of parasites. The nitroradicals enter redox recycling with molecular oxygen, producing partial oxygen reduction favoring the appearance of ROSs. [22]. Due to the synergistic interaction between the drugs utilized in this study and oxidative stress conditions, it may be hypothesized that the use of these glutamate analogs could help to decrease the clinical dose of currently used 


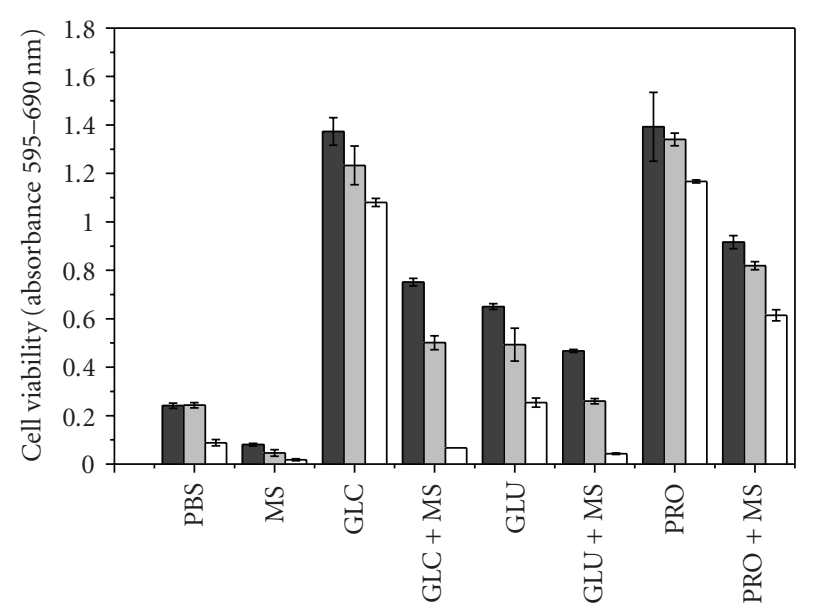

(a)

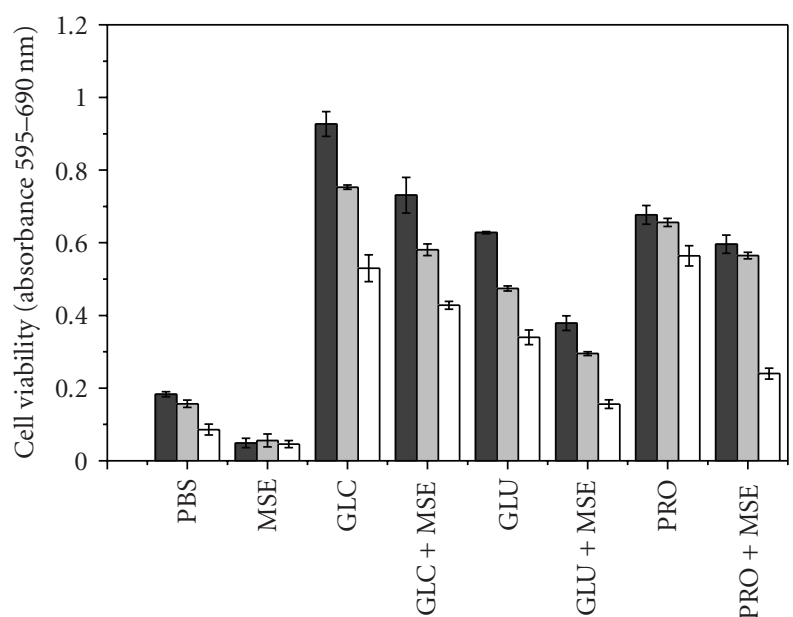

(b)

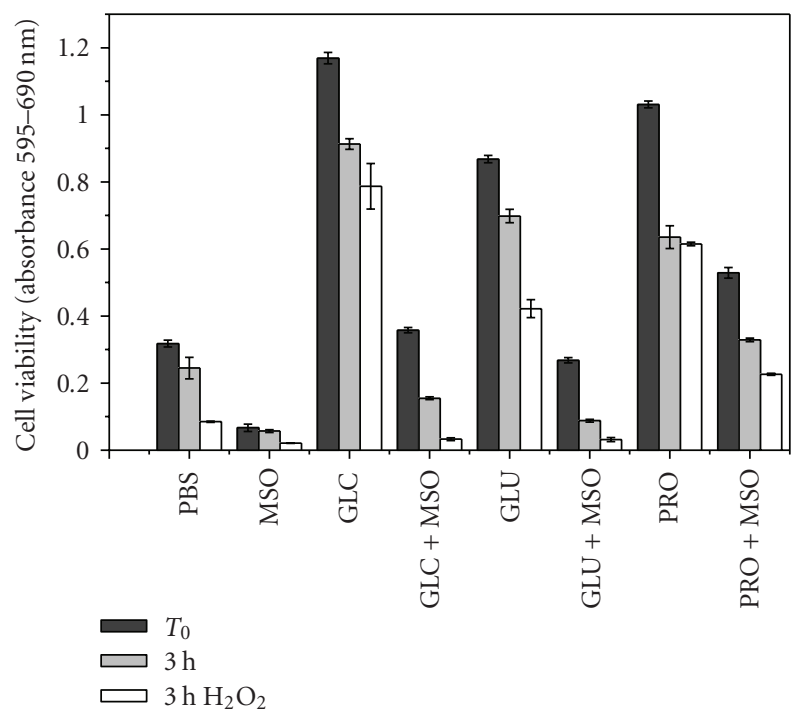

(c)

FIgURE 6: The combined effect of starvation, oxidative stress, and analogues treatments on epimastigotes. Parasites previously incubated in PBS (PBS), $3 \mathrm{mM}$ L-proline in PBS (PRO), or $3 \mathrm{mM}$ glucose in PBS (GLC), and subjected either to oxidative stress for $3 \mathrm{~h}$ by addition of $80 \mu \mathrm{M} \mathrm{H}_{2} \mathrm{O}_{2}$ or to water, were treated with or without (control) $20 \mathrm{mM} \mathrm{MS} \mathrm{(a),} 60 \mathrm{mM} \mathrm{MSE} \mathrm{(b),} \mathrm{or} 50 \mathrm{mM} \mathrm{MSO}$ (c). After washing, the parasites were incubated for $3 \mathrm{~h}$ in PBS and stressed by the addition of $80 \mu \mathrm{M} \mathrm{H}_{2} \mathrm{O}_{2}$. The cell viability was evaluated by MTT assay.

drugs, thereby diminishing the side effects or the length of therapy. Our enzymatic data for the reaction catalyzed by the $\mathrm{NADP}^{+}$-linked glutamate dehydrogenase revealed a higher rate in the direction of the reductive amination of $\alpha$-ketoglutaric acid producing L-glutamate $\left(\mathrm{NADPH}^{+}-\right.$ glutamate dehydrogenase) than the oxidative deamination of L-glutamate ( $\mathrm{NADP}^{+}$-glutamate dehydrogenase) (Figures $7(\mathrm{a})$ and $7(\mathrm{~b}))$. For this later reaction, no significant differences were observed in the presence of L-glutamate and the analogs tested (Figure 7(a)). The data obtained for the glutamate dehydrogenase activities $\left(1.56 \pm 0.23 \mathrm{U} / \mathrm{mg}\right.$ for $\mathrm{NADP}^{+}$ $\mathrm{GDH}$ and $42.22 \pm 3.52 \mathrm{U} / \mathrm{mg}$ for $\mathrm{NADPH}^{+} \mathrm{GDH}$ ) suggest a preference for the glutamate synthesis in the epimastigote stage of T. cruzi (Figures 7(a)-7(b)) [18-20]. Indeed, we also have showed the enzymatic activity levels increased when the glutamate analogs are added (Figure 7(b)). This result shows that T. cruzi, in the conditions above described, would convert these compounds producing oxidized equivalents which are detected by the method herein used. However, further analytical methods are necessary to elucidate the intermediates produced under these conditions. The presence and enzymatic activity for GS was confirmed in $T$. cruzi epimastigotes, suggesting a nutritional requirement for glutamine. This process is ATP-dependent and the glutamine produced would be transaminated (EC: 2.6.1.16) releasing D-glucosamine-6-phosphate. This product is an intermediate of the amino sugars metabolism necessary for the glycoproteins surface synthesis [48]. The specific activities for GS did not show differences in the presence of any of the glutamate analogs tested (Figure 7(c)). All these data 


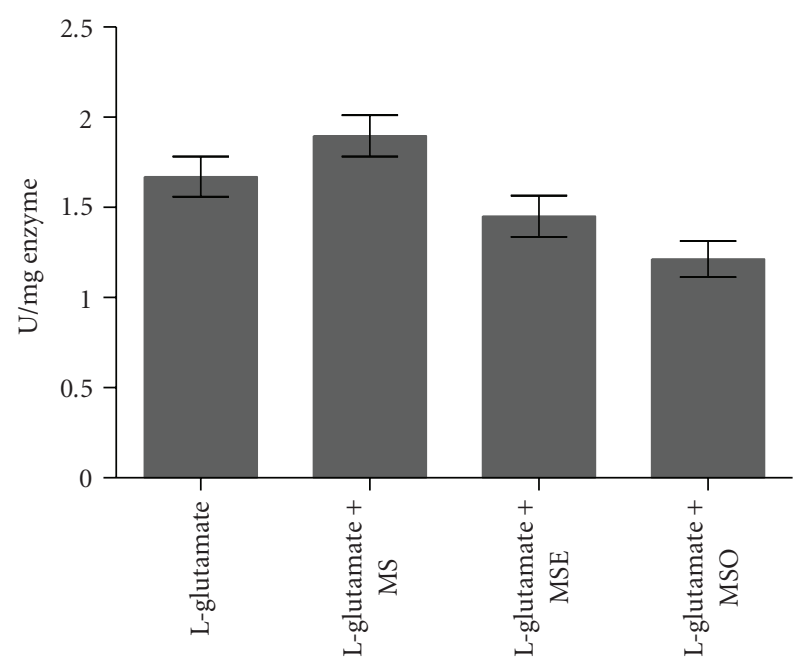

(a) $\mathrm{NADP}^{+}$-glutamate dehydrogenase

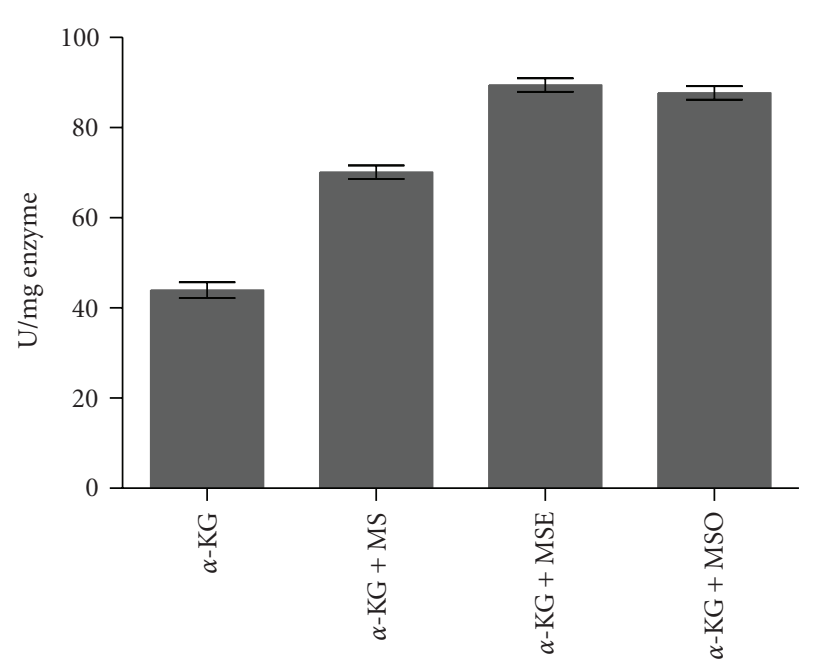

(b) $\mathrm{NADP}^{+}$-glutamate dehydrogenase

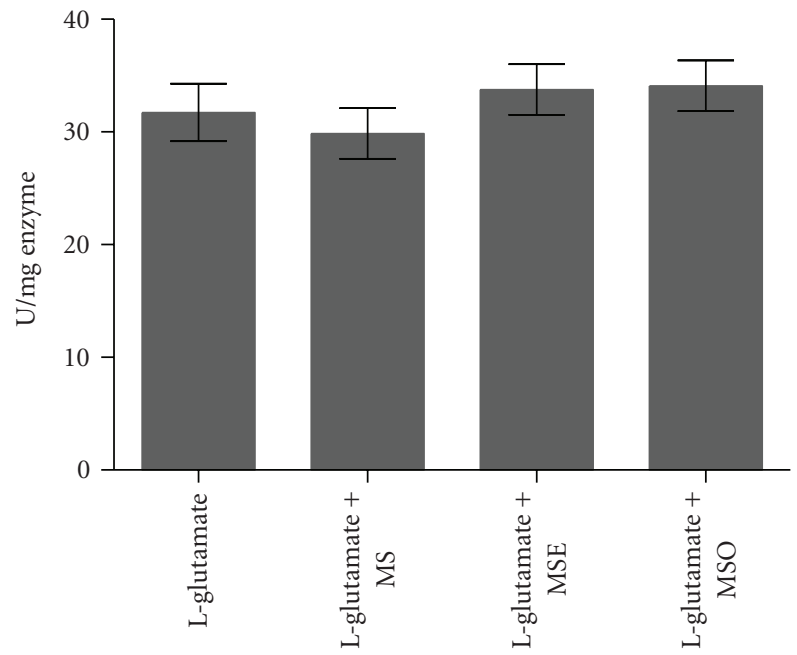

(c) glutamine synthetase

Figure 7: Specific activities for three enzymatic reactions of the glutamate metabolism. Epimastigotes cells $\left(5.0 \times 10^{8}\right.$ cells) were used to prepare the crude extracts as enzyme source. The proteins were quantified by the Bradford's method and the activities for $\mathrm{NADP}^{+}$-glutamate dehydrogenase and glutamine synthetase (GS) were measured. Due to reversibility of the glutamate dehydrogenase reaction, the enzymatic activity was measured in both ways, the reductive amination of $\alpha$-ketoglutaric acid (NADPH $\left.{ }^{+}-\mathrm{GDH}\right)$ and the oxidative deamination of Lglutamate $\left(\mathrm{NADP}^{+}-\mathrm{GDH}\right)$. The bars represent the specific activities in the presence of the natural substrate, as control, and $15 \mathrm{mM}$ of each glutamate analog tested. The graphic was the resultant of three replicates done separately.

support the hypothesis that $T$. cruzi capability to metabolize these compounds interferes in the trypanocidal effects herein evaluated. The higher values of $\mathrm{IC}_{50}$ for these compounds are in accordance with the enzymatic profiles exhibited, even in concentrations of $15 \mathrm{mM}$. for MS, MSE, and MSO.

\section{Materials and Methods}

3.1. Reagents. L-glutamate, L-proline, L-methionine sulfoximine, DL-methionine sulfoxide, DL-methionine sulfone, rotenone, antimycin, and 3-(4,5-dimethylthiazol-2-yl)-2,5diphenyltetrazolium bromide (MTT) were purchased from Sigma Aldrich (Saint Louis, MO, USA). RPMI culture medium and fetal calf serum were purchased from Cultilab (Campinas, SP, Brazil). All other reagents were purchased from Amresco.

3.2. Cells and Parasites. The Chinese hamster ovary cell line, $\mathrm{CHO}-\mathrm{K}_{1}$, was routinely cultivated in RPMI medium (Gibco BRL) supplemented with $10 \%$ heat-inactivated fetal calf serum (FCS), $0.15 \%(\mathrm{w} / \mathrm{v}) \mathrm{NaHCO}_{3}$ at $37^{\circ} \mathrm{C}$ in a humid atmosphere containing $5 \% \mathrm{CO}_{2}$ as previously described [14]. Epimastigotes of T. cruzi, CL strain, clone 14 [49] were maintained at the exponential growth phase by subculturing every $48 \mathrm{~h}$ in liver infusion-tryptose (LIT) medium supplemented with $10 \%$ FCS at $28^{\circ} \mathrm{C}$ [50]. Trypomastigotes were 
obtained by infecting $\mathrm{CHO}-\mathrm{K}_{1}$ cells with trypomastigotes, as previously described [13, 51]. Trypomastigotes were collected in the extracellular medium from the sixth day on.

3.3. Inhibition Growth Assays. Epimastigotes in the exponential growth phase (approximately $5.0 \times 10^{7}$ cells $\mathrm{mL}^{-1}$ ) were centrifuged and resuspended in fresh LIT medium. Then, an inoculum of $2.5 \times 10^{6}$ epimastigotes $\mathrm{mL}^{-1}$ was used. The assays were carried out using $200 \mu \mathrm{L}$ of LIT medium, supplemented with different drug concentrations or without drug treatment (control), on 96 well plates, and maintained at $28^{\circ} \mathrm{C}$. Cell growth was estimated by absorbance readings at $620 \mathrm{~nm}$ every day for a total of 10 days. The optical densities (absorbance) were transformed into cell density values (cells $\mathrm{mL}^{-1}$ ) using a calibration linear equation previously obtained from the same conditions $\left(R^{2}=0.9981\right)$. The concentration of analogs that inhibited $50 \%$ of parasite growth $\left(\mathrm{IC}_{50}\right)$ was determined at the exponential-phase of growth (fifth day) by adjusting the effect (growth inhibition values) as a function of drug concentration to a classical sigmoidal equation. As a control for cell growth inhibition, growth curves were run in parallel for all the experiments in medium containing $200 \mu \mathrm{M}$ rotenone and $0.5 \mu \mathrm{M}$ antimycin [52].

3.4. The Effect of Glutamate Analogs on Growth Inhibition in Stress Conditions. To analyze the combined effect of glutamate analogs at different temperatures, the growth curves were performed as described above and by incubating the cultures at $33^{\circ} \mathrm{C}$ and $37^{\circ} \mathrm{C}$. To evaluate the combined effect of drugs and nutritional stress, $2.0 \times 10^{7}$ epimastigotes $\mathrm{mL}^{-1}$ were washed twice and resuspended in PBS or in PBS supplemented with $3 \mathrm{mM} \mathrm{L}$-glutamate, $3 \mathrm{mM} \mathrm{L}$-proline, or $3 \mathrm{mM}$ glucose. Additional cultures were used in the same conditions but with the addition of $20 \mathrm{mM} \mathrm{MS}, 60 \mathrm{mM}$ MSE, or $50 \mathrm{mM}$ MSO. The parasites were maintained at $28^{\circ} \mathrm{C}$ for $72 \mathrm{~h}$. Then, cell viability was measured by adding $20 \mu \mathrm{L}$ of MTT $\left(5 \mathrm{mg} \mathrm{mL}^{-1}\right)$ at $100 \mu \mathrm{L}$ of cultures in PBS. The cells were maintained at $28^{\circ} \mathrm{C}$, and after three hours the reaction was stopped by adding $20 \mu \mathrm{L}$ of $10 \%$ SDS. The viability was estimated by reading the optical density at $595 \mathrm{~nm}$ and subtracting background values read at $690 \mathrm{~nm}$ [14]. To evaluate the inhibition of epimastigote growth induced by the three analogs under oxidative stress conditions, $5 \times 10^{6}$ parasites $\mathrm{mL}^{-1}$ from stationary phase cultures were washed twice with PBS, and incubated for $90 \mathrm{~min}$ in PBS with or without (control) $120 \mu \mathrm{M} \mathrm{H}_{2} \mathrm{O}_{2}$, and in the presence or not of analogs at $10 \mathrm{mMMS}, 30 \mathrm{mM}$ MSE, or $25 \mathrm{mMMSO}$ (half $\mathrm{IC}_{50}$ concentrations). Then, the cells were collected by centrifugation and resuspended in LIT medium, and after a 5 -day incubation, the number of cells $\mathrm{mL}^{-1}$ was determined as previously described [53]. To evaluate the combined effect of starvation and oxidative stress with drugs, $2.0 \times$ $10^{7}$ epimastigotes $\mathrm{mL}^{-1}$ were washed twice and preincubated for $48 \mathrm{~h}$ at $28^{\circ} \mathrm{C}$ in PBS supplemented with or without $3 \mathrm{mM}$ L-glutamate, $3 \mathrm{mM}$ L-proline, or $3 \mathrm{mM}$ glucose. Additional cultures were run in the same conditions but with the addition of $20 \mathrm{mM}$ MS, $60 \mathrm{mM}$ MSE, or $50 \mathrm{mM}$ MSO (concentrations close to the obtained $\mathrm{IC}_{50}$ ). The cells were then washed twice and resuspended in PBS with or without the addition of $80 \mu \mathrm{M} \mathrm{H}_{2} \mathrm{O}_{2}$, and maintained in those conditions at $28^{\circ} \mathrm{C}$ for $3 \mathrm{~h}$. Then, cell viability was estimated by MTT assay [14].

3.5. Effect of Glutamate Analogs on Mammalian Cell Viability. CHO- $\mathrm{K}_{1}$ cells $\left(5.0 \times 10^{5}\right.$ cells $\left.\mathrm{mL}^{-1}\right)$ were inoculated in 24 well plates in FCS-supplemented RPMI medium as previously described, in the presence of increasing concentrations of analogs or not (controls). The viability of cells was determined by MTT assay and the $\mathrm{IC}_{50}$ was obtained from the adjustment of the data to a typical dose-response sigmoid equation.

\subsection{Effect of Glutamate Analogs on the Trypomastigote} Bursting from Infected Cells. CHO- $\mathrm{K}_{1}$ cells were infected with trypomastigotes in RPMI medium supplemented with $10 \%$ FCS. After $3 \mathrm{~h}$ at $37^{\circ} \mathrm{C}$, free trypomastigotes in the medium were removed by washing with PBS and the infected cells were maintained at $33^{\circ} \mathrm{C}$ in RPMI medium supplemented with $2 \%$ FCS in the presence of different concentrations of glutamate analogs, or without analogs in the case of the control. Fresh medium containing the respective drug was added every day during the intracellular cycle of the parasite. The trypomastigotes were collected in the extracellular medium on the seventh day, and counted in a hemocytometer as previously described $[13,14]$.

\subsection{Effect of Glutamate Analogs on Enzymatic Activities.} In order to determine if the glutamate analogs used in this study would impair the specific activities involved in the glutamate-metabolism enzymes, we have measured, separately, the enzymatic activity for three reactions. The measurements for the $\mathrm{NADP}^{+}$-linked glutamate dehydrogenase $(\mathrm{GDH})$ [EC 1.4.1.4] were done in both senses $[18,20]$. The activities for the reductive amination of $\alpha$-ketoglutaric acid with NADPH dependence $\left(\mathrm{NADPH}^{+}-\mathrm{GDH}\right)$ and the oxidative deamination of L-glutamate with $\mathrm{NADP}^{+}$dependence $\left(\mathrm{NADP}^{+}-\mathrm{GDH}\right)$ were determined. Additionally, the glutamine synthetase activity (GS) [EC 6.3.1.2] was also calculated [21]. In the three cases, the measurements were done in the presence or not of the glutamate analogs MS, MSO, and MSE (sigma). Total cell-free extracts were prepared from epimastigotes forms $\left(5.0 \times 10^{8}\right.$ cells $)$ at mid-log phase (3rd day). The cells were harvested by centrifugation at $2000 \times \mathrm{g}$ and washed three times with saline phosphate buffer $1 \mathrm{X} \mathrm{pH}$ : 7,4 . The resultant pellet was resuspended in lysis buffer containing Tris- $\mathrm{HCl} 20 \mathrm{mM} \mathrm{pH}$ : 7.9, Triton X-100 0.1\%, sucrose $0.25 \mathrm{M}$, phenylmethanesulfonylfluoride (PMSF) $1 \mathrm{mM}$, and $30 \mu \mathrm{L}$ of protease inhibitor cocktail (sigma). The cells were broken by three cycles of sonication/ice during $20 \mathrm{~s}$ at $40 \%$ of potency. Soluble material was separated by centrifugation at $12,000 \times \mathrm{g}\left(4^{\circ} \mathrm{C}-15 \mathrm{~min}\right)$ and the supernatant collected. This fraction was passed through a desalting column (PD10) and eluted with $\mathrm{KH}_{2} \mathrm{PO}_{4} 50 \mathrm{mM} \mathrm{pH}$ : 7.4 for enzymatic activity assays. Total proteins concentration was determined by the Bradford's method [54] using bovine serum albumin as standard. 
3.7.1. Glutamate Dehydrogenase (NADP+-GDH). The assay reaction mixture $(1.5 \mathrm{~mL})$ for determination of $\mathrm{NADP}^{+}-$ GDH activity contained Tris- $\mathrm{HCl} 50 \mathrm{mM} \mathrm{pH}: 8.6, \beta$-nicotinamide adenine dinucleotide phosphate sodium salt trihydrate ( $\beta$-NADP) $25 \mathrm{mM}$, sodium glutamate $20 \mathrm{mM}$. The reaction was started by the addition of crude extract $(100 \mu \mathrm{g})$ and incubated at $30^{\circ} \mathrm{C}$ for $5 \mathrm{~min}$. The increasing of the absorbance at $340 \mathrm{~nm}$ was monitored and a blank without the enzyme addition was used. When necessary, $15 \mathrm{mM}$ of each analog was added to the reaction mix and the corresponding activity was recorded. One activity unit (U) is defined as the amount of enzyme in the crude extract required to catalyze the formation of $1 \mu \mathrm{mol}$ of $\alpha$-ketoglutaric acid from L-glutamate per minute at $30^{\circ} \mathrm{C}$.

3.7.2. Glutamate Dehydrogenase $\left(\mathrm{NADPH}^{+}-\mathrm{GDH}\right)$. The assay reaction mixture $(1.5 \mathrm{~mL})$ for determination of $\mathrm{NADPH}^{+}-\mathrm{GDH}$ activity contained Tris- $\mathrm{HCl} 83 \mathrm{mM}$ pH: 8.3, $\alpha$-ketoglutaric acid $\left(\alpha\right.$-KG) $7.5 \mathrm{mM}, \mathrm{NH}_{4} \mathrm{Cl} 225 \mathrm{mM}$, and $\beta$-nicotinamide adenine dinucleotide phosphate, reduced form, ( $\beta$-NADPH) $0.25 \mathrm{mM}$ (sigma). The reaction was started by the addition of crude extract $(100 \mu \mathrm{g})$ and incubated at $30^{\circ} \mathrm{C}$ for $5 \mathrm{~min}$. The increasing of the absorbance at $340 \mathrm{~nm}$ was monitored and a blank without the enzyme addition was used. When necessary, $15 \mathrm{mM}$ of each analogue was added to the reaction mix and the corresponding activity was recorded. One activity unit $(\mathrm{U})$ is defined as the amount of enzyme in the crude extract required to catalyze the formation of $1 \mu \mathrm{mol}$ of L-glutamic acid from $\alpha$-ketoglutaric acid per minute at $30^{\circ} \mathrm{C}$.

3.7.3. Glutamine Synthetase (GS). A coupled method using the pyruvate kinase/L-lactic dehydrogenase enzymes was necessary for the GS activity determination. The assay reaction mixture $(1.5 \mathrm{~mL})$ contained imidazole- $\mathrm{HCl}$ buffer $34.1 \mathrm{mM} \mathrm{pH}$ : 7.4, sodium glutamate $12 \mathrm{mM}$, adenosin $5^{\prime}$-triphosphate $8.5 \mathrm{mM}$, phosphoenolpyruvate (PEP) $1.5 \mathrm{mM}, \mathrm{MgCl}_{2} 60 \mathrm{mM}, \mathrm{KCl} 18.9 \mathrm{mM}, \mathrm{NH}_{4} \mathrm{Cl} 45 \mathrm{mM}, \beta-$ nicotinamide adenine dinucleotide $0.25 \mathrm{mM}, 28$ units of pyruvate kinase and 40 units of L-lactic dehydrogenase (sigma). The reaction was started by the addition of crude extract $(100 \mu \mathrm{g})$ and incubated at $30^{\circ} \mathrm{C}$ for $10 \mathrm{~min}$. The increasing of the absorbance at $340 \mathrm{~nm}$ was monitored and a blank without the enzyme addition was used. When necessary, $15 \mathrm{mM}$ of each analogue was added to the reaction mix and the corresponding activity was recorded. One activity unit (U) is defined as the amount of enzyme in the crude extract required to catalyze the formation of $1 \mu \mathrm{mol}$ of L-glutamine from L-glutamic acid per minute at $30^{\circ} \mathrm{C}$.

3.8. Statistical Analysis. A one-way analysis of variance (ANOVA) followed by a Dunnet's test was used for statistical analysis. A $P$ value less than. 05 was considered statistically significant. To analyze synergism in the interaction between the two independent treatments, a two-way ANOVA was performed as described [55].

\section{Abbreviations}

$\begin{array}{ll}\text { LIT: } & \text { Liver-infusion tryptose } \\ \text { FCS: } & \text { Fetal calf serum } \\ \text { CHO-K1: } & \text { Chinese hamster ovary cells } \\ \text { PBS: } & \text { Phosphate-buffered saline } \\ \text { RPMI: } & \text { Roswell Park Memorial Institute culture } \\ & \text { medium } \\ \text { GLC: } & \text { Glucose } \\ \text { PRO: } & \text { Proline } \\ \text { GLU: } & \text { Glutamate } \\ \text { IC50: } & \text { 50\% inhibitory concentration } \\ \text { MTT: } & \text { 3-(4,5-dimethylthiazol-2-yl)-2,5- } \\ & \text { diphenyltetrazolium bromide } \\ \text { MS: } & \text { L-methionine sulfoximine } \\ \text { MSO: } & \text { DL-methionine sulfone } \\ \text { MSE: } & \text { DL-methionine sulfoxide } \\ \text { NADP }{ }^{+} \text {-GDH: } & \text { NADP }{ }^{+} \text {-linked glutamate dehydrogenase } \\ \text { GS: } & \text { Glutamine synthetase. }\end{array}$

\section{Acknowledgments}

This work was supported by grants from the Fundação de Amparo à Pesquisa do Estado de São Paulo (FAPESP Grant 08/57596-4), Conselho Nacional de Desenvolvimento Científico e Tecnológico (CNPq) Grant 473906/2008-2 and Instituto Nacional de Biologia Estrutural e Química Medicinal em Doenças Infecciosas (INBEQMeDI) Grant 573607/ 2008-7), Institutos Nacionais de Ciência e Tecnologia (INCT) program from CNPq, FAPESP, and the Ministry of Health. The funders had no role in study design, data collection and analysis, decision to publish, or preparation of the manuscript. A. Magdaleno and B. S. Mantilla contributed equally in this work.

\section{References}

[1] J. H. Maguire, "Chagas' disease_can we stop the deaths?" The New England Journal of Medicine, vol. 355, no. 8, pp. 760-761, 2006.

[2] J. A. Castro, M. M. de Mecca, and L. C. Bartel, "Toxic side effects of drugs used to treat Chagas' disease (American trypanosomiasis)," Human and Experimental Toxicology, vol. 25, no. 8, pp. 471-479, 2006.

[3] M. J. M. Alves and W. Colli, "Trypanosoma cruzi: adhesion to the host cell and intracellular survival," IUBMB Life, vol. 59, no. 4-5, pp. 274-279, 2007.

[4] Z. Brener, "Biology of Trypanosoma cruzi," Annual Review of Microbiology, vol. 27, pp. 347-382, 1973.

[5] W. de Souza, "Cell biology of Trypanosoma cruzi," International Review of Cytology, vol. 86, pp. 197-283, 1984.

[6] A. M. Silber, W. Colli, H. Ulrich, M. J. M. Alves, and C. A. Pereira, "Amino acid metabolic routes in Trypanosoma cruzi: possible therapeutic targets against Chagas' disease," Current Drug Targets-Infectious Disorders, vol. 5, no. 1, pp. 53-64, 2005.

[7] C. A. Pereira, G. D. Alonso, S. Ivaldi et al., "Arginine metabolism in Trypanosoma cruzi is coupled to parasite stage and replication," FEBS Letters, vol. 526, no. 1-3, pp. 111-114, 2002. 
[8] C. A. Pereira, G. D. Alonso, S. Ivaldi et al., "Arginine kinase overexpression improves Trypanosoma cruzi survival capability," FEBS Letters, vol. 554, no. 1-2, pp. 201-205, 2003.

[9] V. T. Contreras, J. M. Salles, and N. Thomas, "In vitro differentiation of Trypanosoma cruzi under chemically defined conditions," Molecular and Biochemical Parasitology, vol. 16, no. 3, pp. 315-327, 1985.

[10] J. J. Homsy, B. Granger, and S. M. Krassner, "Some factors inducing formation of metacyclic stages of Trypanosoma cruzi," Journal of Protozoology, vol. 36, no. 2, pp. 150-153, 1989.

[11] R. M. Martins, C. Covarrubias, R. G. Rojas, A. M. Silber, and N. Yoshida, "Use of L-proline and ATP production by Trypanosoma cruzi metacyclic forms as requirements for host cell invasion," Infection and Immunity, vol. 77, no. 7, pp. 30233032, 2009.

[12] A. M. Silber, R. R. Tonelli, C. G. Lopes et al., "Glucose uptake in the mammalian stages of Trypanosoma cruzi," Molecular and Biochemical Parasitology, vol. 168, no. 1, pp. 102-108, 2009.

[13] R. R. Tonelli, A. M. Silber, M. Almeida-de-Faria, I. Y. Hirata, W. Colli, and J. M. Alves, "L-proline is essential for the intracellular differentiation of Trypanosoma cruzi," Cellular Microbiology, vol. 6, no. 8, pp. 733-741, 2004.

[14] A. Magdaleno, I. Y. Ahn, L. S. Paes, and A. M. Silber, "Actions of a proline analogue, L-thiazolidine-4-carboxylic acid (T4C), on Trypanosoma cruzi," PLoS ONE, vol. 4, no. 2, Article ID e4534, 2009.

[15] P. Rohloff, A. Montalvetti, and R. Docampo, "Acidocalcisomes and the contractile vacuole complex are involved in osmoregulation in Trypanosoma cruzi," Journal of Biological Chemistry, vol. 279, no. 50, pp. 52270-52281, 2004.

[16] P. Rohloff, C. O. Rodrigues, and R. Docampo, "Regulatory volume decrease in Trypanosoma cruzi involves amino acid efflux and changes in intracellular calcium," Molecular and Biochemical Parasitology, vol. 126, no. 2, pp. 219-230, 2003.

[17] A. M. Silber, R. L. G. Rojas, U. Urias, W. Colli, and M. J. M. Alves, "Biochemical characterization of the glutamate transport in Trypanosoma cruzi," International Journal for Parasitology, vol. 36, no. 2, pp. 157-163, 2006.

[18] J. J. Cazzulo, B. M. Franke de Cazzulo, A. I. Higa, and E. L. Segura, "NAD-linked glutamate dehydrogenase in Trypanosoma cruzi," Comparative Biochemistry and Physiology B, vol. 64, no. 1, pp. 129-131, 1979.

[19] J. J. Cazzulo, S. M. Juan, and E. L. Segura, "Glutamate dehydrogenase and aspartate aminotransferase in Trypanosoma cruzi," Comparative Biochemistry and Physiology, vol. 56, no. 3 B, pp. 301-303, 1977.

[20] S. M. Juan, E. L. Segura, and J. J. Cazzulo, "Purification and some properties of the NADP-linked glutamate dehydrogenase from Trypanosoma cruzi," International Journal of Biochemistry, vol. 9, no. 6, pp. 395-400, 1978.

[21] R. A. Caldas, E. F. Araujo, C. R. Felix, and I. Roitman, "Incorporation of ammonium in amino acids by Trypanosoma cruzi," Journal of Parasitology, vol. 66, no. 2, pp. 213-216, 1980.

[22] J. D. Maya, B. K. Cassels, P. Iturriaga-Vásquez et al., "Mode of action of natural and synthetic drugs against Trypanosoma cruzi and their interaction with the mammalian host," Comparative Biochemistry and Physiology A, vol. 146, no. 4, pp. 601-620, 2007.

[23] F. Irigoín, L. Cibils, M. A. Comini, S. R. Wilkinson, L. Flohé, and R. Radi, "Insights into the redox biology of Trypanosoma cruzi: trypanothione metabolism and oxidant detoxification," Free Radical Biology and Medicine, vol. 45, no. 6, pp. 733-742, 2008.
[24] H. J. Schreier and R. W. Bernlohr, "Purification and properties of glutamate synthase from Bacillus licheniformis," Journal of Bacteriology, vol. 160, no. 2, pp. 591-599, 1984.

[25] J. E. Brenchley, "Effect of methionine sulfoximine and methionine sulfone on glutamate synthesis in Klebsiella aerogenes," Journal of Bacteriology, vol. 114, no. 2, pp. 666-673, 1973.

[26] G. Harth and M. A. Horwitz, "Export of recombinant Mycobacterium tuberculosis superoxide dismutase is dependent upon both information in the protein and mycobacterial export machinery: a model for studying export of leaderless proteins by pathogenic mycobacteria," Journal of Biological Chemistry, vol. 274, no. 7, pp. 4281-4292, 1999.

[27] G. Harth and M. A. Horwitz, "Inhibition of Mycobacterium tuberculosis glutamine synthetase as a novel antibiotic strategy against tuberculosis: demonstration of efficacy in vivo," Infection and Immunity, vol. 71, no. 1, pp. 456-464, 2003.

[28] A. M. Silber, R. R. Tonelli, M. Martinelli, W. Colli, and M. J. M. Alves, "Active transport of L-proline in Trypanosoma cruzi," Journal of Eukaryotic Microbiology, vol. 49, no. 6, pp. 441-446, 2002.

[29] R. A. Ronzio, W. B. Rowe, S. Wilk, and A. Meister, "Preparation and studies on the characterization of sheep brain glutamine synthetase," Biochemistry, vol. 8, no. 6, pp. 26702674, 1969.

[30] W. B. Rowe and A. Meister, "Studies on the inhibition of glutamine synthetase by methionine sulfone," Biochemistry, vol. 12, no. 8, pp. 1578-1582, 1973.

[31] P. Barderi, O. Campetella, A. C. C. Frasch et al., "The NADP ${ }^{+}$ linked glutamate dehydrogenase from Trypanosoma cruzi: sequence, genomic organization and expression," Biochemical Journal, vol. 330, no. 2, pp. 951-958, 1998.

[32] N. M. El-Sayed, P. J. Myler, D. C. Bartholomeu et al., "The genome sequence of Trypanosoma cruzi, etiologic agent of chagas disease," Science, vol. 309, no. 5733, pp. 409-435, 2005.

[33] T. A. Minning, D. B. Weatherly, J. Atwood, R. Orlando, and R. L. Tarleton, "The steady-state transcriptome of the four major life-cycle stages of Trypanosoma cruzi," BMC Genomics, vol. 10, article 370, 2009.

[34] R. Tanaka, "New polar constituents of the pupae of the silkworm Bombyx mori L. I. Isolation and identification of methionine sulfoxide, methionine sulfone, and $\gamma$-cyclic di-Lglutamate," Bioscience, Biotechnology and Biochemistry, vol. 71, no. 12, pp. 3055-3062, 2007.

[35] A. Koc, A. P. Gasch, J. C. Rutherford, H. Y. Kim, and V. N. Gladyshev, "Methionine sulfoxide reductase regulation of yeast lifespan reveals reactive oxygen species-dependent and independent components of aging," Proceedings of the National Academy of Sciences of the United States of America, vol. 101, no. 21, pp. 7999-8004, 2004.

[36] L. Berlicki, "Inhibitors of glutamine synthetase and their potential application in medicine," Mini-Reviews in Medicinal Chemistry, vol. 8, no. 9, pp. 869-878, 2008.

[37] C. Y. Chiang, J. Wang, Y. F. Xie et al., "Astroglial glutamateglutamine shuttle is involved in central sensitization of nociceptive neurons in rat medullary dorsal horn," Journal of Neuroscience, vol. 27, no. 34, pp. 9068-9076, 2007.

[38] W. Hilgier, M. Wȩgrzynowicz, M. Mączewski et al., "Effect of glutamine synthesis inhibition with methionine sulfoximine on the nitric oxide-cyclic GMP pathway in the rat striatum treated acutely with ammonia: a microdialysis study," Neurochemical Research, vol. 33, no. 2, pp. 267-272, 2008.

[39] A. Meister, "Glutamine synthetase from mammalian tissues," Methods in Enzymology, vol. 113, pp. 185-199, 1985. 
[40] J. M. Manning, S. Moore, W. B. Rowe, and A. Meister, "Identification of L-methionine S-sulfoximine as the diastereoisomer of L-methionine SR-sulfoximine that inhibits glutamine synthetase," Biochemistry, vol. 8, no. 6, pp. 2681-2685, 1969.

[41] S. Asin and S. Catala, "Development of Trypanosoma cruzi in Triatoma infestans: influence of temperature and blood consumption," Journal of Parasitology, vol. 81, no. 1, pp. 1-7, 1995.

[42] C. Chen, S. Wanduragala, D. F. Becker, and M. B. Dickman, "Tomato QM-like protein protects Saccharomyces cerevisiae cells against oxidative stress by regulating intracellular proline levels," Applied and Environmental Microbiology, vol. 72, no. 6, pp. 4001-4006, 2006.

[43] N. Krishnan, M. B. Dickman, and D. F. Becker, "Proline modulates the intracellular redox environment and protects mammalian cells against oxidative stress," Free Radical Biology and Medicine, vol. 44, no. 4, pp. 671-681, 2008.

[44] E. R. Stadtman, H. van Remmen, A. Richardson, N. B. Wehr, and R. L. Levine, "Methionine oxidation and aging," Biochimica et Biophysica Acta, vol. 1703, no. 2, pp. 135-140, 2005.

[45] A. B. Salmon, V. I. Pérez, A. Bokov et al., "Lack of methionine sulfoxide reductase A in mice increases sensitivity to oxidative stress but does not diminish life span," FASEB Journal, vol. 23, no. 10, pp. 3601-3608, 2009.

[46] X. H. Zhang and H. Weissbach, "Origin and evolution of the protein-repairing enzymes methionine sulphoxide reductases," Biological Reviews, vol. 83, no. 3, pp. 249-257, 2008.

[47] H. Weissbach, F. Etienne, T. Hoshi et al., "Peptide methionine sulfoxide reductase: structure, mechanism of action, and biological function," Archives of Biochemistry and Biophysics, vol. 397, no. 2, pp. 172-178, 2002.

[48] N. W. Andrews, A. M. Katzin, and W. Colli, "Mapping of surface glycoproteins of Trypanosoma cruzi by two-dimensional electrophoresis. A correlation with the cell invasion capacity," European Journal of Biochemistry, vol. 140, no. 3, pp. 599-604, 1984.

[49] Z. Brener and E. Chiari, "Morphological variations observed in different strains of trypanosoma," Revista do Instituto de Medicina Tropical de São Paulo, vol. 19, pp. 220-224, 1963.

[50] E. P. Camargo, "Growth and differentiation in Trypanosoma cruzi. I. Origin of metacyclic trypanosomes in liquid media," Revista do Instituto de Medicina Tropical de São Paulo, vol. 12, pp. 93-100, 1964.

[51] M. Almeida-de-Faria, E. Freymüller, W. Colli, and M. J. M. Alves, "Trypanosoma cruzi: characterization of an intracellular epimastigote-like form," Experimental Parasitology, vol. 92, no. 4, pp. 263-274, 1999.

[52] I. Stolić, K. Mišković, A. Magdaleno et al., "Effect of 3,4ethylenedioxy-extension of thiophene core on the DNA/RNA binding properties and biological activity of bisbenzimidazole amidines," Bioorganic and Medicinal Chemistry, vol. 17, no. 6, pp. 2544-2554, 2009.

[53] J. K. Finzi, C. W. M. Chiavegatto, K. F. Corat et al., “Trypanosoma cruzi response to the oxidative stress generated by hydrogen peroxide," Molecular and Biochemical Parasitology, vol. 133, no. 1, pp. 37-43, 2004.

[54] M. M. Bradford, "A rapid and sensitive method for the quantitation of microgram quantities of protein utilizing the principle of protein dye binding," Analytical Biochemistry, vol. 72, no. 1-2, pp. 248-254, 1976.

[55] B. K. Slinker, “The statistics of synergism," Journal of Molecular and Cellular Cardiology, vol. 30, no. 4, pp. 723-731, 1998. 

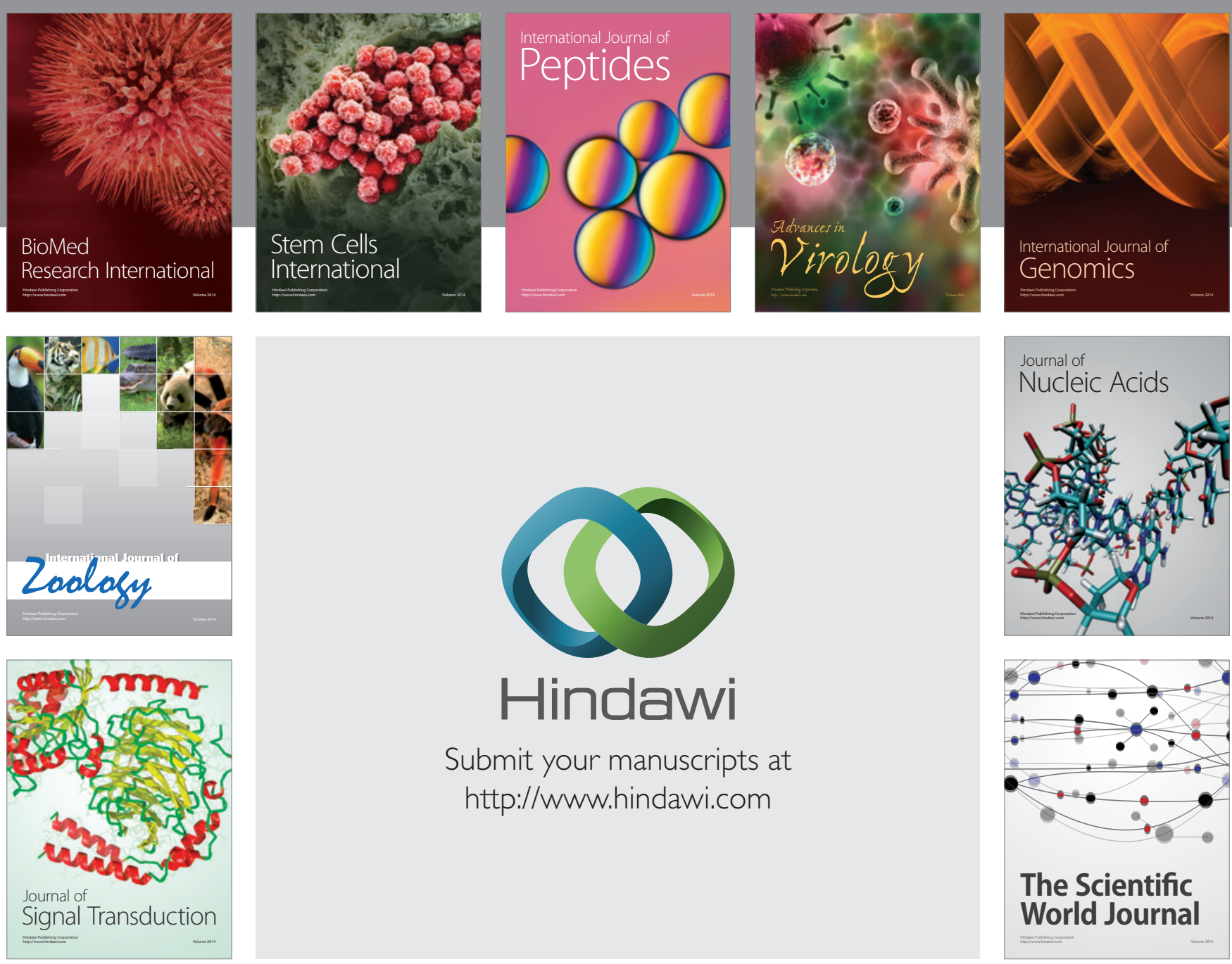

Submit your manuscripts at

http://www.hindawi.com
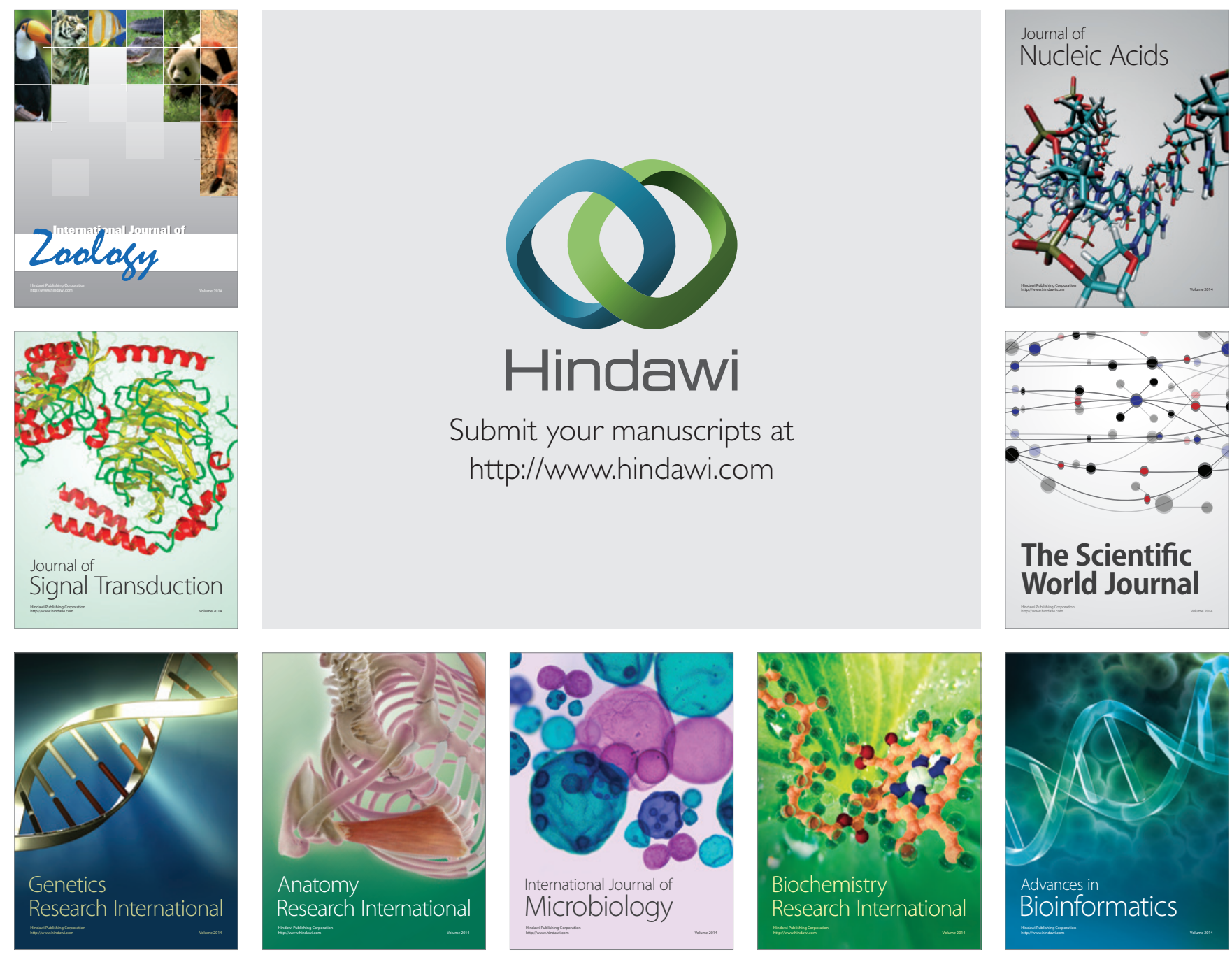

The Scientific World Journal
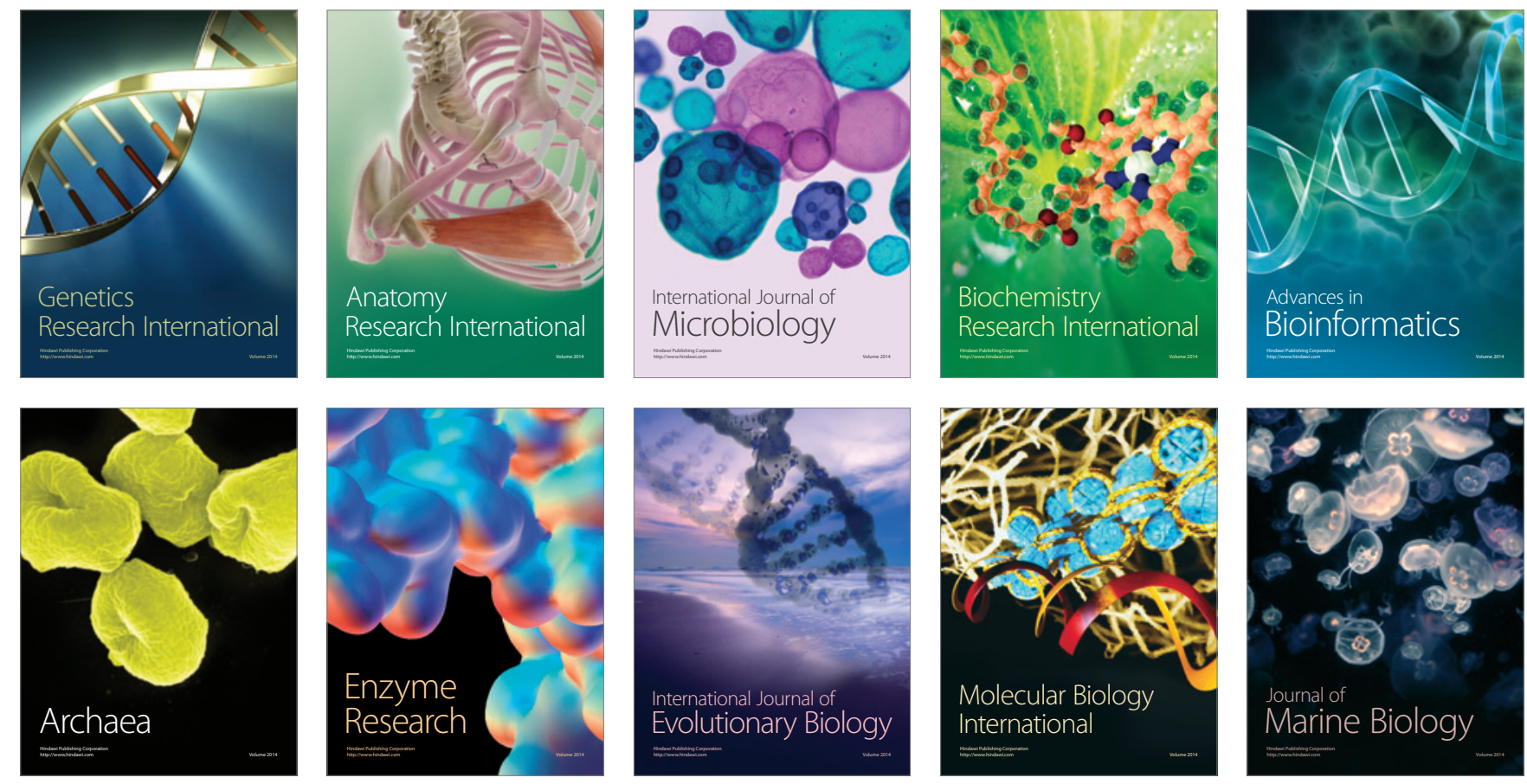